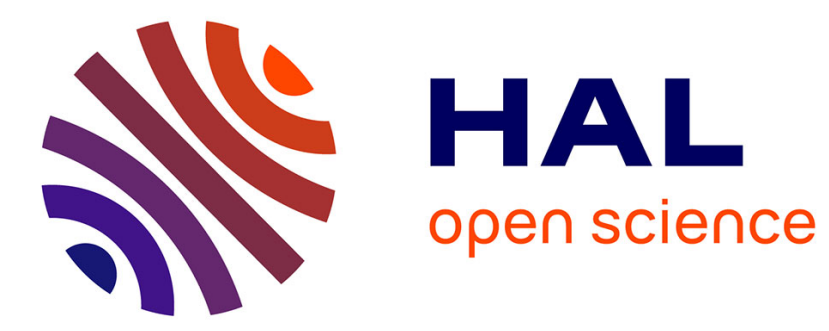

\title{
Intergenerational Earnings Mobility in France: Is France More Mobile than the US?
}

\author{
Arnaud Lefranc, Alain Trannoy
}

\section{To cite this version:}

Arnaud Lefranc, Alain Trannoy. Intergenerational Earnings Mobility in France: Is France More Mobile than the US?. Annales d'Economie et de Statistique, 2005, 78, 10.2307/20079128 . hal-01651123

\section{HAL Id: hal-01651123 \\ https://hal.science/hal-01651123}

Submitted on 1 Apr 2020

HAL is a multi-disciplinary open access archive for the deposit and dissemination of scientific research documents, whether they are published or not. The documents may come from teaching and research institutions in France or abroad, or from public or private research centers.
L'archive ouverte pluridisciplinaire HAL, est destinée au dépôt et à la diffusion de documents scientifiques de niveau recherche, publiés ou non, émanant des établissements d'enseignement et de recherche français ou étrangers, des laboratoires publics ou privés. 


\title{
Intergenerational earnings mobility in France: Is France more mobile than the US?
}

\author{
Arnaud LEFRANC ${ }^{\dagger}$ et Alain TRANNOY‡
}

\begin{abstract}
This paper examines the extent and evolution of intergenerational earnings mobility in France. We use data from five waves of the French Education-Training-Employment (FQP) surveys covering the period 1964 to 1993. Our estimation procedure follows BJÖRKLUND and JÄNTTI (1997)'s two-sample instrumental variable method. On our samples, the elasticity of son's (respectively daughter's) long-run income with respect to father's long run income is around .4 (resp. .3) with no significant change over the period under scrutiny. Comparing these estimates to results obtained from other studies suggests that intergenerational mobility is higher in France than in the United States and United Kingdom and lower than in Scandinavian countries.
\end{abstract}

\section{La mobilité intergénérationnelle de revenu en France : une mobilité plus forte qu'aux États-Unis ?}

RÉSUMÉ. - Cet article estime l'étendue de la mobilité intergénérationnelle de revenu en France, à partir des cinq vagues des enquêtes FormationQualification-Profession (FQP) disponibles sur la période 1964-1993. Nous utilisons la procédure d'estimation par variables instrumentales sur deux échantillons de BJÖRKUND et JÄNTTI (1997). L'élasticité estimée du revenu des fils (respectivement des filles) par rapport au revenu de leur père est de 0.4 (resp. 0.3). La mobilité intergénérationnelle de revenu s'avère plus forte en France qu'aux États-Unis et plus faible que dans les pays scandinaves.

We are grateful to Sam Bowles, Nicolas Gravel, Eric Maurin, Louis-André Vallet and conference participants at ESPE and Journées de Microéconomie Appliquée for helpful comments. We also thank Louis-André Vallet for his help in the implementation of the Erikson and Goldthorpe classification. Financial support from Commissariat Général au Plan is gratefully acknowledged.

† A. Lefranc: THEMA, Université de Cergy-Pontoise, 33 Boulevard du Port, 95011, Cergy-Cedex. Tel : (33) 134256171 ; fax : 0134256233 ; e-mail : arnaud.lefranc@ eco.u-cergy.fr

‡ A. TRANNOY : EHESS, GREQAM-IDEP and THEMA Université de Cergy-Pontoise, 33 Boulevard du Port, 95011 Cergy, France. E-mail : alain.trannoy@eco.u-cergy.fr 


\section{Introduction}

The idea that individual social status and educational attainment is influenced by family and social background has received considerable attention in the sociological literature. Given the paramount influence of these attributes on earnings, one would consequently expect individual earnings to be correlated across generations of a given family, as suggested in the seminal economic model of inheritance developed by BECKER and Tomes $(1979 ; 1986)$. Following earlier empirical studies by Bowles (1972), Bowles and Nelson (1974), Conlisk (1974), AtKinson (1981), a growing number of studies have been devoted to the analysis of intergenerational income mobility. While these studies have dominantly focused on intergenerational income mobility in the United States, several papers have also examined the intergenerational transmission of earnings in other countries including England, Scandinavian countries, Germany and Canada (see Solon ; $(1999 ; 2002)$ for a summary of the international evidence). Beyond the intrinsic interest of measuring intergenerational mobility in each of these countries, comparisons of intergenerational earnings transmission between countries with different labor market institutions, wage structures and educational policy may also provide valuable indications on the mechanisms relating one generation's socio-economic status to the next.

In this perspective, several features of France's socio-economic setting make this country an interesting case for comparison. Firstly, the French labor market is largely viewed as a heavily regulated one yielding a much more compressed wage structure than observed in anglo-saxon economies. Secondly, there has been a important fall in wage inequality over the last 30 years (see for instance Goux and Maurin (2000) and Lefranc (1997)). Thirdly, this period has also been a time of deep reforms of the educational system and of important rise in access to higher education ${ }^{1}$. Lastly, it is worth recalling that college, university and "grandes écoles" education are free of tuition in France.

The objective of this paper is to study the extent and evolution over time of intergenerational earnings mobility in France. We analyze the elasticity of child's earnings in adulthood to father's labor earnings, using five waves of the INSEE Formation-Qualification-Profession labor market surveys, covering the period 1964 to 1994. Our estimation procedure follows BJöRKLUND and JÄNTTI (1997)'s two-sample instrumental variable method.

Several findings emerge from our analysis. Firstly, intergenerational persistence of individual earnings appears rather high in France. Overall, our estimates suggest that the value of intergenerational earning elasticity is about .4, a smaller estimate than most US and UK ones but much higher than estimates found for Nordic countries and Canada. Secondly, our results indicate that intergenerational mobility has remained fairly constant over the 1977-1993 period, despite an important fall in intra-generational earnings inequality over that period.

The rest of the paper is organized as follows. Section 2 discusses a standard intergenerational earnings transmission model. Section 3 presents the economet-

\footnotetext{
1. Before 1975 , lower secondary education was segmented into vocational and general schooling. This dual system was reformed in 1975 under the "réforme Haby" to create a unified junior high-school curriculum. Access to higher education rose markedly, first in the late sixties-early seventies and again, during the late eighties-early nineties.
} 
ric model. Section 4 describes the data. Sections 5 discusses our main results. Section 6 compares our French results to estimates obtained from other studies and in particular to those obtained on US data.

\section{Theoretical framework}

The various sources of intergenerational earnings transmission can be analyzed using a simplified version of the BECKER and TOMEs (1979) model of intergenerational earnings transmission. This model assumes that for each generation, a family only consists of one individual. Consider two generations, father and child, within a given family. Let $f$ index variables pertaining to the father and $c$ index variables pertaining to the child. Individual permanent income $Y$ is assumed to derive from two components: individual endowment in human capital and individual ability denoted by $a$. BECKER and TOMES assume that the child's endowment in human capital is chosen by her father as a result of optimal allocation of father's permanent income, where father's utility depends on father's own consumption and child's permanent income $Y^{c}$. Computing optimal investment in child's human capital yields the following relationship between father and child's permanent income:

$$
Y^{c}=\phi Y^{f}+\theta a^{c}
$$

This equation summarizes BECKER and TOMEs's main relationship. It is sufficient to illustrate different sources of intergenerational earnings correlation. First, equation (1) implies that father's permanent income has a positive causal influence on child's earnings, captured by the parameter $\phi$. Other things equal, an exogenous 1 Euro increase in father's earnings will rise child's earnings by $\phi$ Euros. This source of intergenerational earnings correlation only results from the choice of a higher investment in child's human capital as father's earnings increase. The major rationale for this effect, as discussed, for instance, in BECKER and TOMES (1986) and Mulligan (1997), is that investment in child's human capital, and more generally child's upbringing, is likely to be constrained by parental financial resources, in the presence of imperfect capital markets. Hence, alleviating this constraint will then allow parents to provide their children with a better educational environment which will be translated into higher earnings. MAZUMDER (2001) provides empirical evidence on US data consistent with theoretical models that emphasize borrowing constraints as a major source of intergenerational inequality: using detailed information on wealth, the intergenerational correlation is estimated to be negligible only for families in the top quartile of the distribution of wealth.

A second source of earnings correlation can be present in equation (1) if child's ability $a^{c}$ is correlated to father's ability $a^{f}$. This second effect can be differentiated from the previous one as originating from sources of intergenerational transmission in earnings independent of parental investment decisions and budget constraints. It will encompass all aspects of earnings determinants that "money can't buy" and that can nonetheless be transmitted from one generation to the next. As such, it is likely to include a wide range of social and genetic phenomena such as transmission of IQ, social network or preferences. 
Becker and Tomes distinguish these two sources of intergenerational earnings transmissions on the grounds that the first source, investment in human capital, would arise from rational economic investment decision, hence reflecting a causal impact of parental earings on child's out comes, while the second, ability correlation, would stem from sheer mechanical transmission of individual attributes ${ }^{2}$. From a policy point of view, separating these two sources of intergenerational transmission appears crucial. For instance reducing poverty in the parents generation will succeed in weakening intergenerational inheritance if borrowing constraints are the driving force but will fail if correlation in individual ability is the main source of earnings correlation.

From an empirical perspective, it is important to note that simple regression of child's income on father's income will capture both transmission mechanisms. Hence standard estimates of intergenerational earnings regression will provide an upward biased estimate of the causal effect of parental income on child's income.

In this paper, we do not attempt to separate these different sources of intergenerational earnings correlation and focus instead on the estimation of reduced form intergenerational earnings regression. It is worth emphasizing that eventhough the estimated intergenerational regression coefficient will lack a clear structural interpretation, it however constitutes one important descriptive measure of the extent of intergenerational earnings mobility ${ }^{3}$.

\section{Econometric model}

Letting $Y_{i}^{c}$ now denote the logarithm of child's permanent income in family $i$ and $Y_{i}^{f}$ the logarithm of her father's permanent income, we posit the conventional log-linear regression model:

$$
Y_{i}^{c}=\beta_{0}+\beta Y_{i}^{f}+e_{i}
$$

where $e_{i}$ is a disturbance term independent of $Y_{i}^{f}$ and $\beta$, the coefficient of intergenerational regression in permanent income, is our parameter of interest. This coefficient represents the elasticity of a child's long-run earnings with respect to her father's long run earnings. It differs from the intergenerational correlation coefficient that has been largely used in the sociological literature. If the inequality in $Y$ (measured by the variance of logarithms) remains constant between generations, then the two coefficients are equal. If not, for reasonable changes in permanent earnings inequality between generations, the difference in the two coefficients remains small, as pointed out in Solon (1992). Several reasons make the intergenerational earnings elasticity a more attractive measure of mobility. First, contrary to the correlation coefficient, it can be computed without measuring inequalities in

2. Following the terminology introduced in Black et al. (2003), these two sources of intergenerational earnings transmission can be contrasted as originating from either a causation process (human capital investment under borrowing constraints) or a selection process (mechanical transmission of individual attributes).

3. For a discussion of the causal effect of parental income and education on children outcomes, see MAurin (2002) for France, SHEA (2000) for the United-States and Black et al. (2003) for Norway. 
permanent income in the children and father generations. Second, it seems more in tune with what economists would like to measure. For instance, suppose that, for the children's generation, some policy decreases inequality by reducing all income deviations from the mean by a given factor. We hope to conclude that the inheritance of parental income has decreased with such a policy. Note that in fact, the elasticity coefficient would decrease. Yet, the correlation coefficient would be unaffected by such a transformation which stands at odd with the intuition that intergenerational mobility should have increased.

Given observations of permanent income for successive generations in a sample of families, equation (2) could be directly estimated by ordinary least squares. Unfortunately, most data sets usually provide much more limited information on both children's and father's earnings and socio-economic status. As pointed out in recent papers, these limitations of available data rise several estimation problems.

Firstly, most data sets only provide measures of current earnings (usually as of the survey date) and fail to provide measures of individual permanent income. As shown in SOLON (1992) and ZiMMERMAN (1992), using current earnings as a shortrun proxy for permanent income will lead to the common attenuation bias in estimates of $\beta$, due to the presence of transitory components in current earnings.

Different solutions have been offered to reduce or eliminate this bias. The first one relies on panel data on fathers' earnings and consists in using an average of fathers' current earnings over several years as a proxy for permanent income. This "averaging procedure" reduces the share of transitory components and measurement errors in the variance of the independent variable and consequently dampens the attenuation bias. A common alternative is to resort to instrumental variable (IV) estimation to estimate $\beta$ using current measures of children's and father's earnings. Several variables have been used in the literature to instrument father's current earnings, including father's socio-economic status, education, union status and industry. Properties of IV estimates of $\beta$ will obviously depend on the ability of the set of instruments to pick up inter-individual variance in permanent income. Solon (1992) also notes that if the instruments have an independent effect on children's permanent income beside their effect through father's permanent income, IV estimates of $\beta$ may be biased, since the usual assumption that the instrument have no separate impact on the explanatory variable will be violated. In particular, instruments such as father's education or social status are likely to have a direct positive impact on child's achievement and income and may lead to estimates of $\beta$ that will be upward biased. Results reported in BJÖRKLUND and JäNTTI (1997), comparing different estimation procedures, lent some support to this conjecture ${ }^{4}$.

A second estimation problem arises when available data provide information only on father's socio-demographic characteristics and not on father's earnings. In this case, $\beta$ can still be estimated, as long as a prediction of father's permanent income can be formed based on recorded father's socio-demographic characteristics. This procedure calls for an auxiliary sample that provides information on earnings and socio-demographic characteristics in the fathers' generation. It was introduced by BJÖRKLUND and JÄNTTI (1997).

Let the log of father's current earnings at date $t, Y_{i t}^{f}$, be given by:

$$
Y_{i t}^{f}=Y_{i}^{f}+u_{i t}^{f}
$$

4. CoRCoran et al. (1990) provide contradictory evidence that once parental income is controlled for, parental and social class seem to have very limited independent impact on child's earnings. 
where $u_{i t}^{f}$ incorporates transitory fluctuations in father's current earnings and measurement error. Assume further that children's log current income is related to children's log permanent earnings in a similar way and that $u_{i t}^{f}$ and $u_{i t^{\prime}}^{c}$ are uncorrelated. Let $Z_{i}^{f}$ denote a set of socio-demographic characteristics (e.g. education) of fathers from a sample of families $i \in I$ and assume that $Y_{i t}^{f}$ can be written as:

$$
Y_{i t}^{f}=Z_{i}^{f} \gamma+v_{i}^{f}+u_{i t}^{f}
$$

where $v_{i t}^{f}$ is independent of $Z_{i}^{f} . Y_{i t}^{f}$ is not observed in sample $I$. Yet, if there exists a sample $J$ from the same population as $I$, it can be used to provide an estimate $\hat{\gamma}$ of $\gamma$, derived from the estimation of :

$$
Y_{j t}^{f}=Z_{j}^{f} \gamma+v_{j}^{f}+u_{j t}^{f}
$$

for $j \in J$. From this, one can form a prediction of father's earnings in sample $I$. This prediction can in turn be used to estimate $\beta$ since equations (2), (3) and (5) imply:

$$
Y_{i t}^{c}=\beta_{0}+\beta\left(Z_{i}^{f} \hat{\gamma}\right)+\eta_{i t}
$$

where $\eta_{i t}=e_{i}+u_{i t}^{c}+\beta v_{i}^{f}+\beta\left(Z_{i}^{f}(\gamma-\hat{\gamma})\right)$.

Estimates of $\beta$ provided in this paper are based on the estimation of equations (5) and (6) on separate samples, described in the following section. Equations (5) and (6) are estimated with OLS, unless otherwise stated, and standard errors of estimates from equation (6) are corrected for heteroscedasticity ${ }^{5}$. To account for lifecycle profiles in earnings, omitted from the above discussion, estimation of both equations include additional control for individual or father's age. Note that this estimation procedure is similar to the IV estimation discussed above, using $Z_{i}^{f}$ as instrumental variables, except for the fact that first-step estimates are taken from a different sample than second-step estimates. This estimation procedure appears as an application of ANGRIST and KRUEGER (1995)'s split-sample instrumental-variables estimator. It can be shown that it is asymptotically equivalent to standard IV estimates if samples $I$ and $J$ are drawn from the same population. Hence, two-samples instrumental-variables estimates of $\beta$ may also be subject to an upward bias, as discussed above.

In the end, not having direct information on father's earnings, in our data sets, appears as a minor limitation, to the extent that error-in-variables bias would have imposed IV estimation and that small sample size in our data could have suggested the use of ANGRIST and KRUEGER's split-sample instrumental variable procedure.

\section{Data description}

\subsection{The FQP surveys}

Our data are taken from the first five waves of the FQP (Formation, Qualification, Profession) surveys conducted by INSEE in 1964, 1970, 1977, 1985 and 1993. A

5. Heteroscedasticity is taken into account using the HuBER-WHITE sandwich estimator of the variance. 
new sample is drawn for each wave, so that the data do not have a panel structure. The number of individuals surveyed varies across waves: 25000 individuals in 1964, 38000 from 1970 to 1985 and 19000 in 1993. For all waves but 1993, individuals surveyed are taken from a stratified sample of the French population of working age, with different sampling probabilities for each stratus. All estimates are adjusted using sampling weights ${ }^{6}$.

For all individuals surveyed, the data contain detailed information on education, as well as training, labor market experience, 4-digits occupation and industry when relevant. Individual annual earnings (excluding unemployment benefits) in the previous year and number of months worked full- and part-time are also collected in all waves except 1964. This year, annual earnings are recorded in interval form, using 9 intervals. Hence, all estimations results reported for wave 1964 are based on interval regression. In all waves earnings refer to labor earnings and are only recorded for salaried workers.

All surveys provide information about the respondent's current family (marital status, number of children) and family of origin (number of siblings, respondent's birth rank). Waves 1977 through 1993 also contain a detailed description of the educational attainment and 2-digits occupation of the father of the respondent, and information about the geographical location of the respondent's parents. This information is reported a posterio by survey respondents and refer to the time when the respondent left the schooling system.

In all waves, education is recorded using a 10 levels education classification that distinguishes between general and vocational education. For both education and occupation, classifications changed several time over the five waves. We recoded both variables using a consistent classification across survey waves. Occupation is recoded using the ERIKSON and GoldTHORPE (1991) social position schema. Education is recoded using a 8 levels classification. The classifications used in this paper are presented in the appendix.

\subsection{Samples selection rules}

Our estimates are based on several samples of children and fathers.

Our samples of children are taken from waves 1977, 1985 and 1993 of the FQP surveys. In each wave, our sample is restricted to individuals aged 30 to 40 years old as of the survey date and being either head of household or spouse of the household head. Individuals with rank of birth in their family of origin higher than or equal to 3 are excluded ${ }^{7}$. This restriction is imposed to limit the interval of allowable ages for fathers in each wave (see below). Since we do not observe earnings for self-employed individuals, we also exclude self-employed children as well as children whose father was self-employed from our samples of children. Individuals reporting zero annual earnings and those reporting full-time full-year equivalent earnings below half the minimum wage are excluded from most regressions. We also check for possible sample selection biases.

6. Adjusting for sampling weights is particularly justified in our case, since -a- there might be heterogeneity in intergenerational earnings correlation and -b- we are interested in average intergenerational correlation in earnings. Nevertheless, adjusting for weights only have a minor impact on estimates.

7. We also performed the estimation without this restriction. To do this we considered fathers between 25 and 40 years old at the time of children' birth. Results, that can be obtained from the authors upon request, are very similar to those reported in tables 1 to 3. LindAHL (2002) provides comparable results for Sweden, indicative that family size has no influence on intergenerational earnings elasticity. 
Our samples of fathers are taken from waves 1964 through 1985 of the FQP surveys. Several fathers sample can be matched to each of the 1977, 1985 and 1993 children samples, each fathers sample corresponding to a survey wave preceding the survey wave of the children sample ${ }^{8}$ : for instance, our 1993 children sample will be matched to four father samples drawn from waves 1985, 1977, 1970, 1964; our 1985 children sample will be matched to three fathers samples $(1977,1970$, 1964), ... We select individuals into the fathers samples by assuming that fathers of individuals from our children samples where aged between 25 and 30 years old at the time of the children's birth ${ }^{9}$. Since we restrict children samples to individuals aged 30 to 40 years old, a children sample from wave $w$ will be matched to a fathers sample from wave $w^{\prime}$ composed of individuals aged $30+25-w+w$ ' to $40+30-w+w$ ' years old. We also impose that individuals from the fathers samples report at least one child, are not self-employed and are head of household.

\subsection{Sample description}

Our final samples of children consist of 771 (FQP93), 2114 (FQP85) and 2023 (FQP77) sons and 629 (FQP93), 1502 (FQP85) and 1046 (FQP77) daughters. Differences in the size of sons and daughters samples arise from the survey sampling scheme.

Tables 5 and 6 in the appendix report the main descriptive statistics for our sons and daughters samples. For sons, the distribution of educational attainment appears roughly unchanged when samples are restricted to individuals who report positive annual earnings. On the contrary, in our samples of daughters, individuals reporting positive earnings have higher education than the overall sample suggesting sample selection. As pointed out by COUCH and LiLlard (1998), dropping observations if children report zero earnings might introduce a selection bias which calls for an adequate econometric treatment.

Table 7 compares children's report of their father's education and social position to the composition of the relevant fathers samples. For all waves, the distributions of fathers' education and social position based on children's report appear broadly consistent in the sons and daughters samples. When differences exist between average sons and daughters reports, there does not appear to be any systematic pattern of misreporting. Children's report also appear consistent with the distribution of education and social status computed from our samples of fathers, indicating that children's fathers and pseudo-fathers samples are likely drawn from the same population.

\section{Results}

\subsection{Main results}

Table 1 reports intergenerational regression coefficients for annual earnings. Estimates in this table are obtained using father's education and social status as

\footnotetext{
8. We experiment using the different waves eventhough recorded education and occupation of parents refer to the time the respondents finished initial schooling.

9. Our samples indicate that mean father's age at the birth of the first child is around 27 years.
} 
TABLE 1

\section{Intergenerational regression in annual earnings}

\begin{tabular}{|c|c|c|c|c|c|c|c|c|c|}
\hline \multirow{3}{*}{$\begin{array}{l}\text { children sample } \\
\text { fathers sample }\end{array}$} & \multicolumn{4}{|c|}{93} & \multicolumn{3}{|c|}{85} & \multicolumn{2}{|c|}{77} \\
\hline & 64 & 70 & 77 & 85 & 64 & 70 & 77 & 64 & 70 \\
\hline & (1) & $(2)$ & (3) & (4) & $(5)$ & (6) & (7) & (8) & (9) \\
\hline & \multicolumn{9}{|c|}{ Panel A: sons } \\
\hline \multirow[t]{2}{*}{ age } & .020 & .020 & .020 & .020 & .023 & .023 & .023 & .020 & .020 \\
\hline & $(.007)$ & $(.007)$ & $(.007)$ & $(.007)$ & $(.003)$ & $(.003)($ & $(.003)$ & $(.003)$ & $(.003)$ \\
\hline \multirow[t]{2}{*}{ father's earnings } & .414 & .400 & .438 & .436 & .342 & .363 & .377 & .398 & .432 \\
\hline & $(.061)$ & $(.056)$ & $(.06)$ & $(.06)$ & $(.026)$ & $(.027)($ & $(.028)$ & $(.026)$ & $(.027)$ \\
\hline \multirow[t]{2}{*}{ Const. } & 8.089 & 7.496 & 7.165 & 5.944 & 7.669 & 6.885 & 6.470 & 6.680 & 5.691 \\
\hline & $(.469)$ & $(.522)$ & $(.556)$ & $(.726)$ & $(.238)$ & $(.289)($ & $(.321)$ & $(.247)$ & $(.291)$ \\
\hline Obs. & 703 & 703 & 703 & 703 & 1976 & 1976 & 1976 & 1823 & 1823 \\
\hline \multirow[t]{2}{*}{$R^{2}$} & .084 & .092 & .092 & .09 & .118 & .124 & .124 & .191 & .207 \\
\hline & \multicolumn{9}{|c|}{ Panel B: daughters } \\
\hline \multirow[t]{2}{*}{ age } & .017 & .017 & .017 & .017 & .018 & .018 & .018 & .014 & .013 \\
\hline & $(.009)$ & $(.009)$ & $(.009)$ & $(.009)$ & $(.007)$ & $(.007)($ & (.007) & $(.01)$ & $(.01)$ \\
\hline \multirow[t]{2}{*}{ father's earnings } & .317 & .298 & .331 & .330 & .278 & .297 & .312 & .228 & .240 \\
\hline & $(.084)$ & $(.076)$ & $(.084)$ & $(.084)$ & $(.052)$ & $(.054)($ & $(.054)$ & $(.08)$ & $(.089)$ \\
\hline \multirow[t]{2}{*}{ Const. } & 8.461 & 8.082 & 7.797 & 6.869 & 8.021 & 7.374 & 6.99 & 7.842 & 7.340 \\
\hline & $(.644)$ & $(.708)$ & $(.768)$ & $(.991)$ & $(.444)$ & $(.53)($ & $(.562)$ & $(.61)$ & $(.791)$ \\
\hline Obs. & 552 & 552 & 552 & 552 & 1342 & 1342 & 1342 & 933 & 933 \\
\hline$R^{2}$ & .035 & .039 & .04 & .039 & .051 & .054 & .056 & .026 & .027 \\
\hline
\end{tabular}

Note: second-step estimates of the two-step model, using father's education and social class as instruments. Dependant variable is log annual labor earnings. Father's earnings refers to the log of fathers annual labor earnings. Robust standard errors in parentheses.

a predictor for father's annual earnings. First-step estimates of father's earning regression are given in table 8 in the appendix. In all regressions in table 1, father's predicted log earnings has a significant positive effect on child's earnings.

For sons (panel A), regression coefficients are around .41 in the 1993 children sample, .36 in 1985 and .41 in 1977. For daughters (panel B), regression coefficients are around .32 in 1993, .29 in 1985 and .23 in 1977. Whether for sons or daughters samples, differences across time in the estimated regression coefficients are not statistically significant at conventional levels and the degree of intergenerational persistence in earnings appears broadly constant across the 1977-1993 period. Consequently, the important decrease in intragenerational earnings inequality documented in several papers (see for instance Goux and MAURIN (2000) and LEFRANC (1997) has not led to an increase in intergenerational earnings mobility ${ }^{10}$.

10. At first glance, the values of the R-squared reported in table 1 do not seem to support this conclusion. For sons, the R-squared decreases over the period, from around $20 \%$ to less than $10 \%$. Since the R-squared measures the share of the variance in children's (log) earnings accounted for by differences in father's earnings, this evolution seems to suggest that mobility has indeed risen. However, one should be careful with this interpretation, since the dependant variable in the regressions is current, not lifetime, earnings. Hence, the rise in earnings instability that has occurred during the period under study will lead to a fall in the regression's R-squared, even if intergenerational mobility (as defined by the correlation in lifetime earnings) remains constant over time. 
TABLE 2

Additional estimates of regression in annual earnings

\begin{tabular}{|c|c|c|c|c|c|c|c|c|c|}
\hline \multirow{3}{*}{$\begin{array}{l}\text { children sample } \\
\text { fathers sample }\end{array}$} & \multicolumn{4}{|c|}{93} & \multicolumn{3}{|c|}{85} & \multicolumn{2}{|c|}{77} \\
\hline & 64 & 70 & 77 & 85 & 64 & 70 & 77 & 64 & 70 \\
\hline & (1) & (2) & (3) & (4) & (5) & (6) & (7) & (8) & (9) \\
\hline & \multicolumn{9}{|c|}{ Panel A: sons } \\
\hline
\end{tabular}

instruments for

father's earnings:

education

$\begin{array}{lllllllll}.440 & .428 & .430 & .456 & .421 & .471 & .423 & .444 & .497\end{array}$

$\begin{array}{llllll}(.073) & (.068)(.068)(.072) & (.032)(.035)(.033) & (.03)(.032)\end{array}$

social group

$\begin{array}{lllllllll}.406 & .384 & .422 & .420 & .295 & .316 & .331 & .380 & .408\end{array}$

education, social

$\begin{array}{llllll}(.067)(.059)(.064)(.062) & (.027)(.028) & (.03) & (.027)(.028)\end{array}$

group, indicator

$\begin{array}{llllllllll}\text { for Paris, indicator } & .433 & .422 & .463 & .460 & .343 & .363 & .377 & .384 & .414\end{array}$

$\begin{array}{lllllll}\text { for rural area } & (.054)(.049)(.055)(.056) & (.025) & (.027) & (.028) & (.025) & (.027)\end{array}$

Panel B: daughters

\begin{tabular}{|c|c|c|c|}
\hline $\begin{array}{l}\text { instruments for } \\
\text { father's earnings: } \\
\text { education }\end{array}$ & $\begin{array}{rrrr}.397 & .374 & .372 & .393 \\
(.105) & (.099) & (.099) & (.104)\end{array}$ & $\begin{array}{rrr}.377 & .423 & .379 \\
(.049) & (.054) & (.049)\end{array}$ & $\begin{array}{ll}.146 & .154 \\
(.12) & (.139)\end{array}$ \\
\hline social group & $\begin{array}{llll}.282 & .270 & .299 & .300\end{array}$ & $\begin{array}{lll}.239 & .261 & .274 \\
(056) & (058) & (062)\end{array}$ & $\begin{array}{ll}.251 & .267 \\
(072) & (076)\end{array}$ \\
\hline $\begin{array}{l}\text { education, social } \\
\text { group, indicator } \\
\text { for Paris, indicator } \\
\text { for rural area }\end{array}$ & $\left.\begin{array}{rrrr}.402 & .370 & .404 & .403 \\
(.078) & (.07)(.077) & (.077)\end{array}\right)$ & $\begin{array}{ccc}.318 & .332 & .347 \\
(.051) & (.053) & (.055)\end{array}$ & $\begin{array}{rr}.169 & .179 \\
(.085) & (.094)\end{array}$ \\
\hline
\end{tabular}

In the light of these coefficients, intergenerational mobility also appears higher for daughters than for sons: for all children-father pairs, estimated regression coefficient are 15 to $40 \%$ lower for daughters than for sons. The estimates are always less precise for daughters than for sons. Nevertheless, equality of earnings regression coefficients between sons and daughters is only rejected at the level of $5 \%$ in 1977 and also partly in 1985. It is however puzzling that, whatever the waves or the specifications, the estimated intergenerational elasticity is systematically higher for sons than for daughters. In fact, this result should not be surprising. For older generations, supporting educational achievements of sons might be considered more important in view of the traditional role of breadwinner fulfilled by men. In a symmetric way, a smaller investment in daughters than in sons might be vindicated by the fact that daughter's earnings can be supplemented by husband's earnings. This priority granted to sons would be conveyed by a higher value of the parameter $\phi$ for sons than for daughters in the theoretical model exposed in the section 2. Since women are getting more and more independent from a financial viewpoint, this 
TABLE 3

\section{Intergenerational regression in wages}

\begin{tabular}{|c|c|c|c|c|c|c|c|c|c|}
\hline \multirow{3}{*}{$\begin{array}{l}\text { children sample } \\
\text { fathers sample }\end{array}$} & \multicolumn{4}{|c|}{93} & \multicolumn{3}{|c|}{85} & \multicolumn{2}{|c|}{77} \\
\hline & 64 & 70 & 77 & 85 & 64 & 70 & 77 & 64 & 70 \\
\hline & (1) & (2) & (3) & (4) & $(5)$ & (6) & (7) & (8) & (9) \\
\hline & \multicolumn{9}{|c|}{ Panel A: sons } \\
\hline \multicolumn{10}{|c|}{ linear regression model } \\
\hline father's wage & $\begin{array}{r}.424 \\
(.048)\end{array}$ & $\begin{array}{r}.415 \\
(.045)\end{array}$ & $\begin{array}{r}.451 \\
(.048)\end{array}$ & $\begin{array}{r}.455 \\
(.051)\end{array}$ & $\begin{array}{r}.343 \\
(.023)\end{array}$ & $\begin{array}{r}.379 \\
(.025)\end{array}$ & $\begin{array}{r}.388 \\
(.026)\end{array}$ & $\begin{array}{r}.398 \\
(.025)\end{array}$ & $\begin{array}{r}.452 \\
(.027)\end{array}$ \\
\hline \multicolumn{10}{|c|}{ sample selection model } \\
\hline father's wage & $\begin{array}{r}.429 \\
(.043)\end{array}$ & $\begin{array}{r}.421 \\
(.041)\end{array}$ & $\begin{array}{r}.457 \\
(.043)\end{array}$ & $\begin{array}{r}.462 \\
(.045)\end{array}$ & $\begin{array}{l}.349 \\
(.02)\end{array}$ & $\begin{array}{r}.380 \\
(.021)\end{array}$ & $\begin{array}{r}.384 \\
(.021)\end{array}$ & $\begin{array}{r}.407 \\
(.021)\end{array}$ & $\begin{array}{r}.458 \\
(.022)\end{array}$ \\
\hline$\lambda$ & $\begin{array}{l}-.281 \\
(.035)\end{array}$ & $\begin{array}{l}-.279 \\
(.034)\end{array}$ & $\begin{array}{l}-.277 \\
(.035)\end{array}$ & $\begin{array}{l}-.281 \\
(.034)\end{array}$ & $\begin{array}{r}-.217 \\
(.026)\end{array}$ & $\begin{array}{l}-.215 \\
(.027)\end{array}$ & $\begin{array}{l}-.216 \\
(.027)\end{array}$ & $\begin{array}{r}-.272 \\
(.028)\end{array}$ & $\begin{array}{r}-.267 \\
(.028)\end{array}$ \\
\hline
\end{tabular}

Panel B: daughters

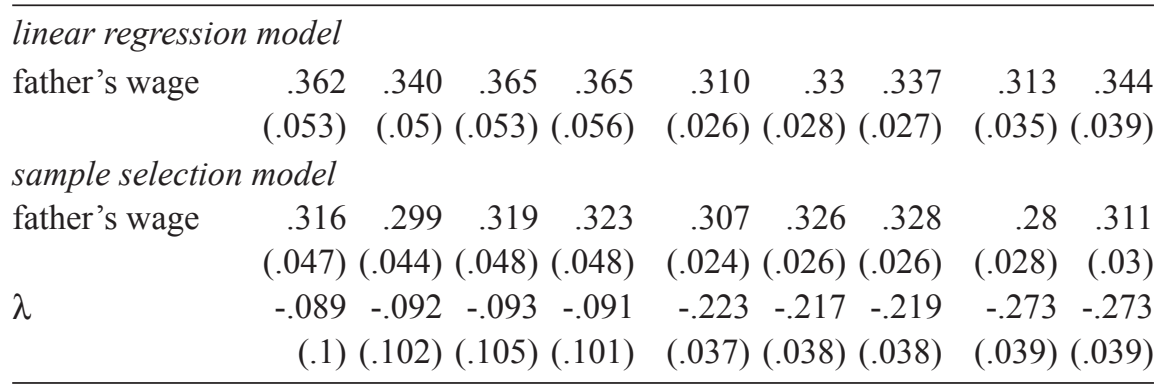

Note: second-step estimates of the two-step model, using father's education and social class as instruments. Dependant variable is log monthly wage, where monthly wage is defined as annual labor earnings divided by the sum of number of months worked full-time plus half the number of months worked part time. Father's wage refers to the log of fathers monthly wage. Sample selection model estimated with maximum likelihood estimation. $\lambda$ denotes the inverse of the Mill's ratio. Selection equation includes father's log predicted earnings, age, indicator for residence in the Paris area, as well as marital status and number of children in the case of our daughter's samples and individual education in the case of our son's sample. Robust standard errors in parentheses.

argument seems less and less relevant and a wild guess would be that the discrepancy between intergenerational elasticities for sons and daughters will completely vanish for younger generations. Results in Table 1 are supportive of this analysis, since the values of the elasticity appear much closer between sons and daughters in the last wave than in the first. However, this feature is not entirely confirmed by results from complementary regressions.

Table 2 reports estimates obtained when using different instrumental variables for fathers earnings. For sons, estimated regression coefficients appear very stable with respect to the set of instruments used. Using father's social position as the only instrumental variable or adding dummy variables for living in Paris and living in a rural area have a very limited impact on estimated coefficients. Using father's education as the only instrumental variable leads to slightly higher regression coefficients. This result is consistent with SoLON's remark that IV estimates will be upward driven if instruments have an independent effect on children's earnings. 
Yet one should note that estimated coefficients are not significantly different across specifications.

Estimates for daughters appear more sensitive to the set of instrumental variables used in the first-step regression. For 1993 and 1985, using education as the only instrument leads to higher estimates and using social position only slightly decreases the estimated regression coefficient. The reverse seems to hold for the 1977 children sample. Again, one should be careful in interpreting these differences since none of them appears significant at conventional levels. Finally, using the broadest set of instruments increases regression coefficients for 1993 and 1985 and decreases them for 1977. As a consequence, differences in regression coefficients between sons and daughters only appear statistically significant in 1977.

Our description of regression in annual earnings can be complemented by the analysis of regression coefficients for monthly wages given in table 3 . Monthly wage is computed by adjusting annual earnings for the number of months worked full-time and part-time ${ }^{11}$. Estimates in table 3 use father's education and social status as instruments for fathers earnings and can be readily compared to estimates in table 1. Each panel of the table reports estimates from linear regression on the first line. The next lines report estimates accounting for sample selection in wages and obtained from maximum likelihood estimation of the selection model ${ }^{12}$.

For sons, regression coefficients for monthly wages are higher than for annual earnings but the difference in estimated coefficients appears moderate. For daughters, regression coefficients are also higher for monthly wage. This is especially true for our 1985 and 1977 children samples. Indeed, using this alternative wage variable, the intergenerational earnings regression coefficient appears remarkably constant for daughters, contrary to what table 1 may suggest. Accounting for sample selection does not affect estimated regression coefficients.

These higher regression coefficients for monthly wages indicate that children's number of months worked both part-time and full-time are less strongly correlated to fathers wages and earnings than individual wages. This suggests that participation decisions and employment constraints are likely to weaken the intergenerational elasticity in earnings potential, especially for women in the earlier waves of our samples. Given the precision of our estimates, this interpretation is yet only tentative.

\subsection{Sources of earnings correlation}

One interesting feature of the two-sample instrumental variable estimation implemented in this paper is that it allows for a straightforward decomposition of the sources of earnings correlation across generations. Assume for simplicity that both children's and fathers' log permanent income are observed and that each can be expressed as:

$$
Y_{i}^{g}=E d u c_{i}^{g} \gamma_{e}^{g}+\operatorname{Soc}_{i}^{g} \gamma_{s}^{g}+v_{i}^{g} \text { for } g=c, f
$$

11. Monthly wage is set equal to annual earnings divided by the number of months worked full-time plus half the number of months worked part-time.

12. The selection equation includes father's log predicted earnings, age, indicator for residence in the Paris area, as well as marital status and number of children in the case of our daughter's samples and individual education in the case of our son's sample. 
where Educ and Soc respectively denote measures of individual's education and social status. ${ }^{13}$

Our two-step estimate of $\beta$ is simply given by:

$$
\beta=\frac{\operatorname{cov}\left(Y_{i}^{c}, E d u c_{i}^{f} \gamma_{e}^{f}+\operatorname{Soc}_{i}^{f} \gamma_{s}^{f}\right)}{\mathrm{V}\left(E d u c_{i}^{f} \gamma_{e}^{f}+\operatorname{Soc}_{i}^{f} \gamma_{s}^{f}\right)}
$$

Expanding terms using equation (7), $\beta$ can be written as:

$$
\begin{aligned}
\beta=\frac{1}{\mathrm{~V}\left(E d u c_{i}^{f} \gamma_{e}^{f}+\operatorname{Soc}_{i}^{f} \gamma_{s}^{f}\right)} \times\left[\gamma_{e}^{c} \operatorname{cov}\left(E d u c_{i}^{c}, E d u c_{i}^{f}\right) \gamma_{e}^{f}+\gamma_{s}^{c} \operatorname{cov}\left(\operatorname{Soc}_{i}^{c}, E d u c_{i}^{f}\right) \gamma_{e}^{f}\right. \\
+\gamma_{e}^{c} \operatorname{cov}\left(E d u c_{i}^{c}, \operatorname{Soc}_{i}^{f}\right) \gamma_{s}^{f}+\gamma_{s}^{c} \operatorname{cov}\left(\operatorname{Soc}_{i}^{c}, \operatorname{Soc}_{i}^{f}\right) \gamma_{s}^{f} \\
\left.+\operatorname{cov}\left(v_{i}^{c}, E d u c_{i}^{f}\right) \gamma_{e}^{f}+\operatorname{cov}\left(v_{i}^{c}, \operatorname{Soc}_{i}^{f}\right) \gamma_{s}^{f}\right]
\end{aligned}
$$

Hence $\beta$ can be decomposed into the sum of six terms corresponding to the covariance of fathers education and social status on children's education, social status and earnings residual, each multiplied by the effect of the relevant variable on children's and fathers' permanent income respectively. Note that this decomposition should only be seen as a descriptive device along the lines suggested in BowLES and GinTis (2002) and not as an analysis of causal effects.

We apply this decomposition to our estimates of annual earnings elasticities. Results are given in table 4. They can be read as follows: assuming that the only channel of intergenerational earnings correlations would work through the correlation of father and child's education, earnings regression coefficient for our 1993 sons sample, using our 1964 father sample, would be equal to .0419 .

It appears from this table that for all years and samples and for both sons and daughters, the bulk of the intergenerational correlation in earnings arises from the correlation between fathers and children social position and the associated earnings coefficients. This finding was already noted in ÖsTERBACKA (2001) for Finland using a related methodology. As expected, father's social status also influences intergenerational elasticity through its effect on children's education. Adding up both effects of father's social status accounts for more than half of the intergenerational elasticity coefficient. Comparatively, father's education accounts for a smaller share of intergenerational regression in earnings and most of the effect of this variable arises from the correlation between father's education and child's social position. Lastly, the respective contribution of father's education and social status to regression in earnings appears remarkably constant across our different children waves. The rather limited contribution of differences in father's education should not be surprising since the distribution of education in the sample of fathers appears strongly concentrated among low education groups. Consequently, father's education is a much less accurate predictor of child's socio-economic background. What could appear more surprising is that the size of the different effects working through the education of the child has not changed markedly between 1977 and 1993, despite, among other things, an important increase in

13. Age effects are ignored here for ease of exposition but are taken into account in the empirical implementation of the decomposition. 
TABLE 4

Decomposition of earnings regression coefficient

\begin{tabular}{|c|c|c|c|c|c|c|c|c|c|}
\hline \multirow{3}{*}{$\begin{array}{l}\text { children sample } \\
\text { fathers sample }\end{array}$} & \multicolumn{4}{|c|}{93} & \multicolumn{3}{|c|}{85} & \multicolumn{2}{|c|}{77} \\
\hline & 64 & 70 & 77 & 85 & 64 & 70 & 77 & 64 & 70 \\
\hline & (1) & (2) & (3) & (4) & (5) & (6) & (7) & (8) & (9) \\
\hline
\end{tabular}

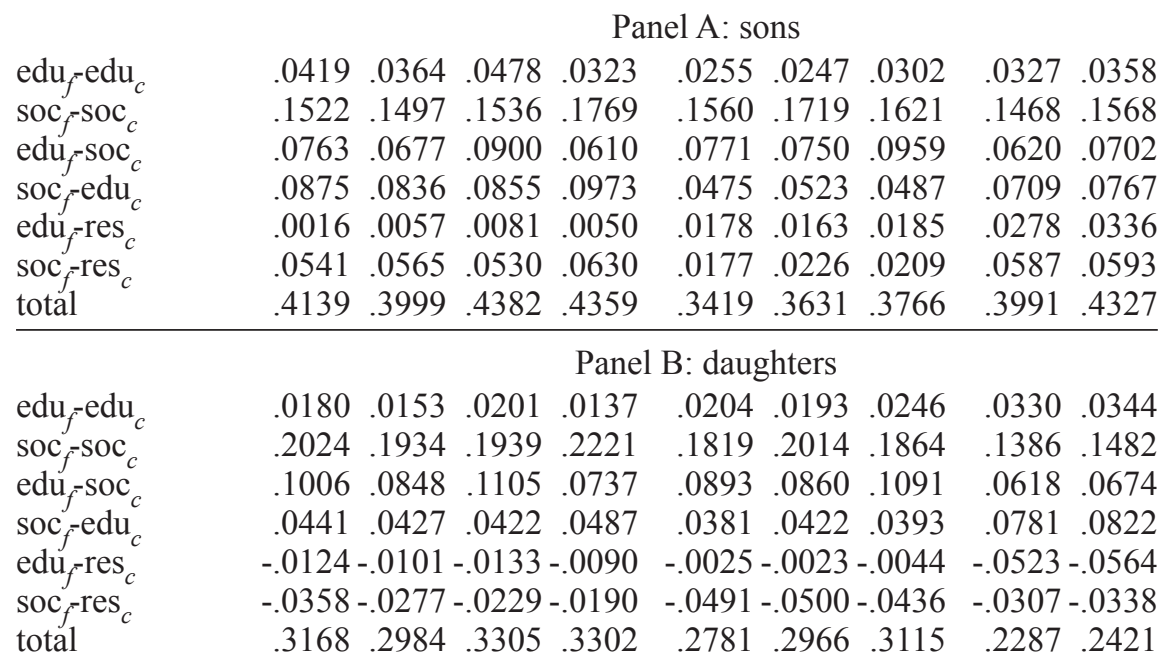

Note: $X_{f} Y_{c}$ denotes the contribution of the correlation between father's $X$ variable and child's $Y$ variable to the correlation between father and child's earnings.

the average educational attainment over this period. In fact, this result confirms previous findings that social mobility has remained roughly constant over the past decades (Goux and Maurin, 1997).

\section{Discussion and conclusion}

Our estimates of intergenerational income elasticity on two generations in France can be compared to results obtained for other countries. We will restrict the comparison to developed countries with similar economic and political background. In comparing our estimates to those of other studies, one should be aware of the potential impact of differences in both the definition of the children's samples and in the estimation method applied. As an example, in the US case, estimated intergenerational earnings elasticities range from a low .13 to as high as .61. For instance, in his 1988 presidential address to the American Economic Association, GARY BECKER (1988) argued that his estimates of 0.2 for the intergenerational elasticity testified to the American dream of strong social fluidity. However, this estimate, based on a one-year observation of father's and child's earnings is now viewed as seriously downward biased by the presence of transitory earnings components as discussed in section 3. SoLON (1999) provides an extensive survey of 
recent US results and concludes: "All in all, .4 or a bit higher also seems a reasonable guess of the intergenerational elasticity in long-run earnings for men in the United States". This conclusion is rooted in studies using multi-year averages of father and child earnings, computed from panel data, as a measure of individual permanent income. The incidence of error-in-variables biases has in fact been further emphasized in a recent paper by MAZUMDER (2001) who provides an even less rosy picture of intergenerational mobility in the US. Using a long panel of social security files, he was able to average individual earnings over a considerably longer period than previous studies. His main findings is that the larger the time span over which earnings are averaged, the higher is the intergenerational elasticity. Averaging earnings over a period of 16 years leads to an elasticity of 0.613 . In the light of these estimates, the American dream seems much less promising. ${ }^{14}$

Regarding the overall level of intergenerational mobility, a good benchmark for comparing our estimates to results from other countries is provided by BJÖRKLUND and JÄNTTI (1997), a study that appears very close to ours, both in terms of the sample definition and the method used. Their result point to an elasticity of .52 for the United-States and .28 for Sweden. Comparing estimates obtained with the two-stage instrumental variables to those obtained from the 'averaging' procedure described in section 3, they further suggest that the two-stage procedure may yield higher, possibly upward biased ${ }^{15}$, estimates of $\beta$. DEARden, Machin et ReED (1997) also estimate elasticity in earnings for Britain with different procedures, one of which is similar to ours. Their smallest IV estimate for $\beta$ is 0.558 for sons leading them to conclude that "regression estimates suggest that, depending in the econometrics method used, the intergenerational mobility parameter $\beta$ is of order of 0.40 to 0.60 for men and 0.45 to 0.70 for women". Overall, comparing our findings to results obtained for other countries, using similar estimation procedures, indicates that France displays more intergenerational mobility than the US and Britain but less than Sweden.

A tentative explanation of this rather surprising result, as France and US are concerned, may underline the difference in the way higher education is financed in these two countries. In the former country, access to higher education is free, while in the latter payment of tuition may be a problem for poor households, even if generous grants are available for bright students. Hence, in the presence of borrowing constraints, parental wealth may bite more in the US than in France. But clearly this is not a definite answer and, as the US literature suggests, the estimates of the intergenerational income elasticity obtained here for France should be confirmed by using richer French data sets or different estimation methods.

Evidence available for other countries and surveyed in Solon (2002) suggest a rather high degree of intergenerational mobility in Finland (ÖsterbACKA, 2001) and Canada (Corak and HeIsz, 1999) ( $\beta$ around .2 or lower). There is some empirical evidence (see for instance Couch and DunN (1997)) that correlation in annual earnings for father-son pairs is fairly similar in Germany and in the United States.

Overall, our results hint at France's intermediate rank in the intergenerational mobility scale, between a group of mobile societies including Nordic countries and

14. Complementary results by HerTz (2005) also document that the black-white mobility gap contributes an important fraction of the intergenerational persistence of inequality.

15. While Solon argues forcefully that the IV procedure might introduce an upward bias, it is puzzling to notice that the estimates found by MAZUMDER are closer to those obtained by BJöRKLUND and JÄNTTI than to those obtained by SOLON. 
Canada and a group of less mobile countries composed of England and the UnitedStates. It is striking that the same broad ranking of countries emerge from international comparisons of inequality (see for instance GotTSCHALK and SMEEDING (2000) and Sastre and Trannoy (2001)). As such, more unequal societies tend to be less mobile, a feature which calls for some theoretical explanations.

Two final remarks are also in order, regarding differences between sons and daughters and time trends. Results in MAZumder (2001) indicate that in the US the elasticity in earnings between fathers and daughters is of the same magnitude as between fathers and sons. Our results suggests, that in France, especially in the earlier waves of our surveys, intergenerational mobility may be higher for daughters than for sons, eventhough the equality of the coefficients cannot be rejected for the more recent waves. Lastly, intergenerational mobility appears fairly constant for cohorts fifteen years apart which suggests that important reforms of the French educational system that started in the 1960's may not have been very successful in increasing social fluidity. For the US, the story which emerges (see for instance HARDING et al. (2001)) is similar to France: there is basically no trend except for a small improvement in the sixties. This calls for further analysis of the mechanisms underlying intergenerational earnings transmission.

\section{References}

Angrist J.D. and Krueger A.B. (1995). - « Split-Sample Instrumental Variables Estimates of the Return to Schooling », Journal of Business and Economic Statistics, 13(150), pp. 225-35.

AtKinson A. (1981). - « On Intergenerational Income Mobility in Britain », Journal of PostKeneysian Economics, 3(2), pp. 194-218.

Becker G. and Tomes N. (1979). - «An Equilibrium Theory of the Distribution of Income and Intergenerational Mobility », Journal of Political Economy, 87(6), pp. 1153-89.

Becker G. and Tomes N. (1986). - «Human Capital and the Rise and Fall of Families », Journal of Labor Economics, 4(3), S1-S39.

BeCKer G.S. (1988). $-\wedge$ «Family Economics and Macro Behavior », American Economic Review, 78(1), pp. 1-13.

BJöRKLUND A. and JäNTTI M. (1997). - «Intergenerational Income Mobility in Sweden Compared to the United States ", American Economic Review, 87(5), pp. 1009-18.

Black S., Devereux P. and Salvanes K. (2003). - «Why the Apple Doesn't Fall Far: Understanding the Intergenerational Transmission of Education », NBER Working Paper.

Bowles S. (1972). - «Schooling and Inequality from Generation to Generation », Journal of Political Economy, 80(3), S219-S51.

Bowles S. and GinTis H. (2002). - « The Inheritance of Inequality », Journal of Economic Perspectives, 16(3), pp. 3-30.

Bowles S. and Nelson V.I. (1974). - « The "Inheritance of IQ" and the Intergenerational Reproduction of Economic Inequality », Review of Economics and Statistics, 56(1), pp. 39-51.

Chadwick L. and Solon G. (2002). - «Intergenerational Income Mobility Among Daughters », American Economic Review, 92(1), pp. 335-44.

Conlisk J. (1974). - «Can Equalization of Opportunity Reduce Social Mobility?», American Economic Review, 64(1), pp. 80-90.

CoraK M. and Heisz A. (1999). - «The Intergenerational Income Mobility of Canadian Men », Journal of Human Resources, 34, pp. 504-33. 
Corcoran M., Gordon R., Laren D. and Solon G. (1990). - «Effects of Family and Community Background on Economic Status », American Economic Review, 80, pp. 362-6.

Couch K.A. and Dunn T.A. (1997). - «Intergenerational Correlations in Labor Market Status: A Comparison of the United States and Germany ", Journal of Human Resources, 32(1), pp. 210-32.

Couch K.A. and Lillard D.R. (1998). - « Sample Selection Rules and the Intergenerational Correlation of Earnings », Labour Economics, 5(3), pp. 313-29.

Dearden L., Machin S. and Reed H. (1997). - «Intergenerational Mobility in Britain », Economic Journal, 107(440), pp. 47-66.

Erikson R. and Goldthorpe J. (1991). - « The Constant Flux: A Study of Class Mobility in Industrial Society », Clarendon Press, Oxford.

Gottschalk P. and Smeeding T. (2000). - «Empirical Evidence on Income Inequality in Industrial Countries », in A.B. Atkinson and F. Bourguignon (eds.), Handbook of Income Distribution, Vol. 1, North-Holland, pp. 261-308.

Goux D. and Maurin E. (1997). - « Meritocracy and Social Heredity in France: Some Aspects and Trends ", European Sociological Review, 13, pp. 159-77.

Goux D. and Maurin E. (2000). - «The Decline in Demand for Unskilled Labor: An Empirical Analysis Method and Its Application to France ", Review of Economics and Statistics, 82(4), pp. 596-607.

Harding D., Jencks C., Lopoo L. and Mayer S. (2001). - « Trends in Intergenerational Economic Mobility: Theories and Estimates for the US since $1960 »$ mimeo Harvard University.

Hertz T. (2005). - « The Intergenerational Economic Mobility of Black and White Families in the United States », in S. Bowles, H. Gintis and M. Osborne (eds.), Unequal Chances: Family Background and Economic Success, Russel Sage Foundation and Princeton University Press, Princeton NJ.

LEFRANC A. (1997). - «Évolutions des marchés du travail français et américains : quelques éléments d'analyse comparative », Revue Économique, 48(5), pp. 1041-60.

Lindahl L. (2002). - « Do Birth Order and Family Size Matter for Intergenerational Income Mobility? Evidence from Sweden », SOFI Working Paper.

MAURIN E. (2002). - « The Impact of Parental Income on Early Schooling Transitions: A ReExamination Using Data over Three Generations », Journal of Public Economics, 85(3), pp. 301-32.

MAZumder B. (2001). - « Earnings Mobility in the US: A New Look at Intergenerational Inequality », University of California, Berkeley, Center for Labor Economics Working Paper.

Mulligan C.B. (1997). - «Galton Versus the Human Capital Approach to Inheritance », Journal of Political Economy, 107(6), S184-S224.

Sastre M. and Trannoy A. (2001). - «Une décomposition de l'évolution de l'inégalité en France avec une perspective internationale 1985-1995 », Rapport du Conseil d'Analyse Économique - Inégalités Économiques, Vol. 33, pp. 315-32.

ShEA J. (2000). - « Does Parents' Money Matter? », Journal of Public Economics, 77(2), pp. $155-84$.

Solon G. (1992). - «Intergenerational Income Mobility in the United States », American Economic Review, 82(3), pp. 393-408.

Solon G. (1999). - «Intergenerational Mobility in the Labor Market», in D. Card and O. Ashenfelter (eds.), Handbook of Labor Economics, Vol.3B, North-Holland, Amsterdam, chapter 29, pp. 1761-1800.

Solon G. (2002). - « Cross-Country Differences in Intergenerational Earnings Mobility », Journal of Economic Perspectives, 16(3), pp. 59-66.

Österbacka E. (2001). - «Family Background and Economic Status in Finland», Scandinavian Journal of Economics, 103(3), pp. 467-84.

Zimmerman D. (1992). - « Regression toward Mediocrity in Economic Stature », American Economic Review, 82(1), pp. 409-29. 


\section{APPENDIX}

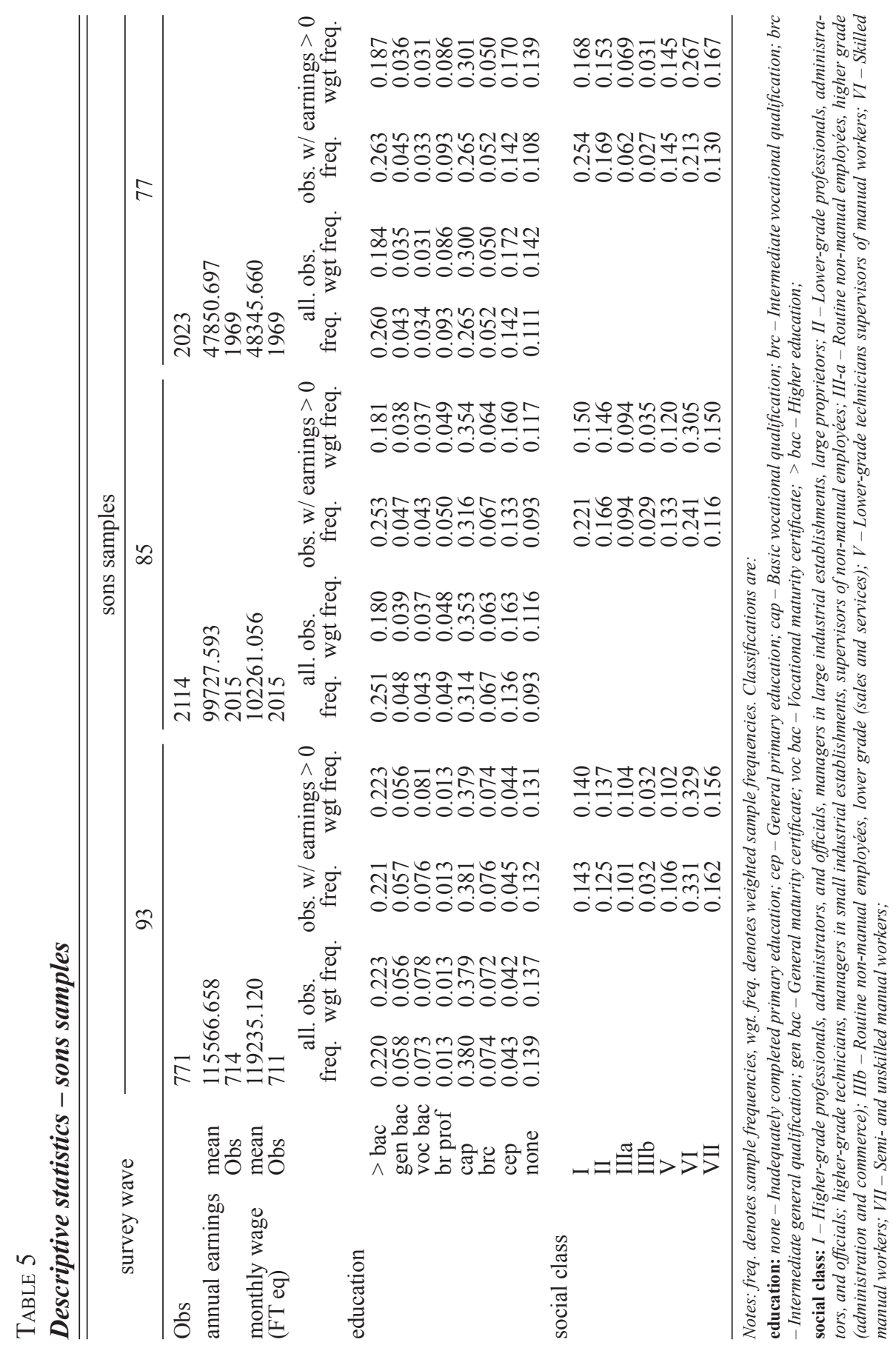




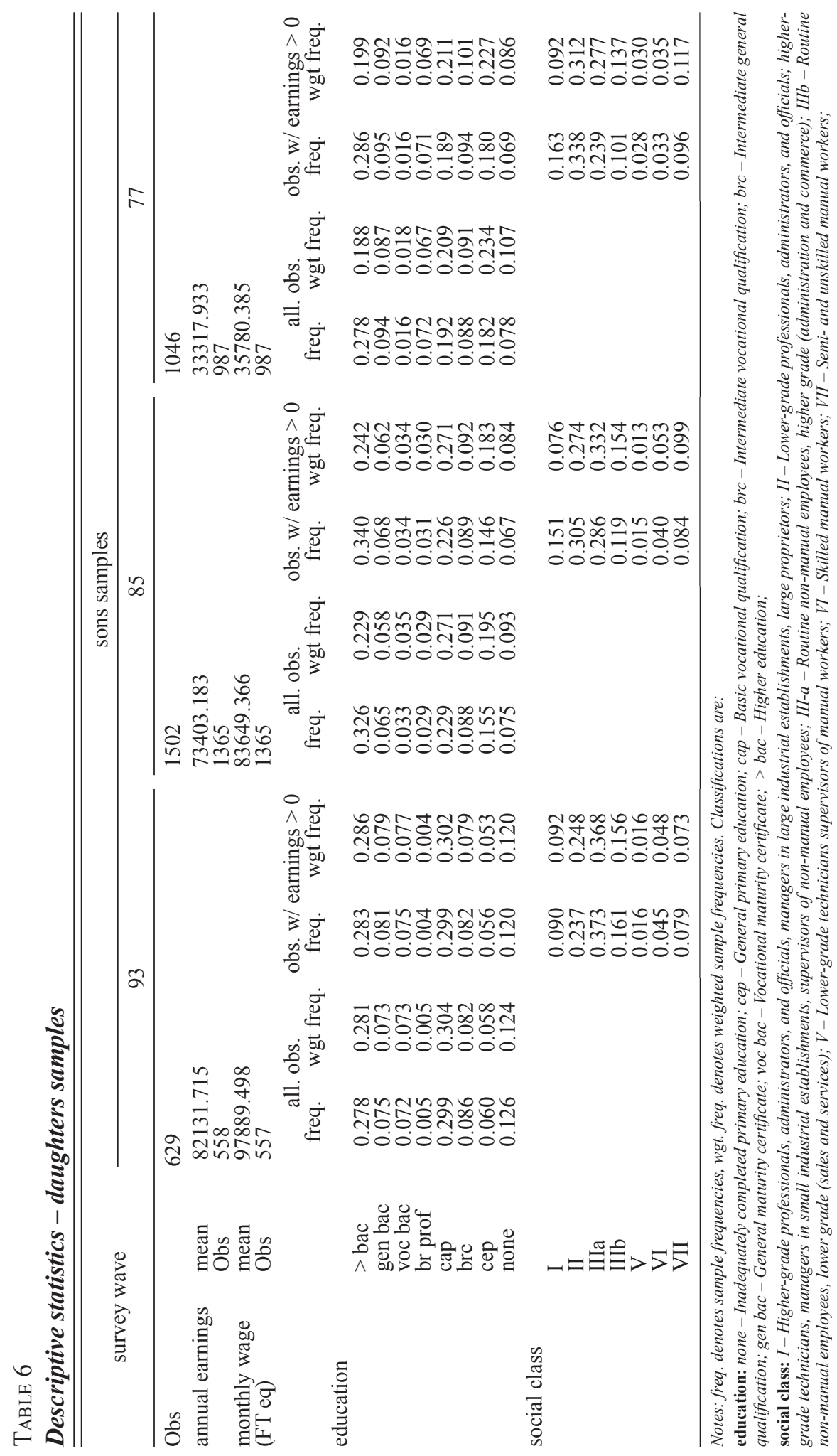




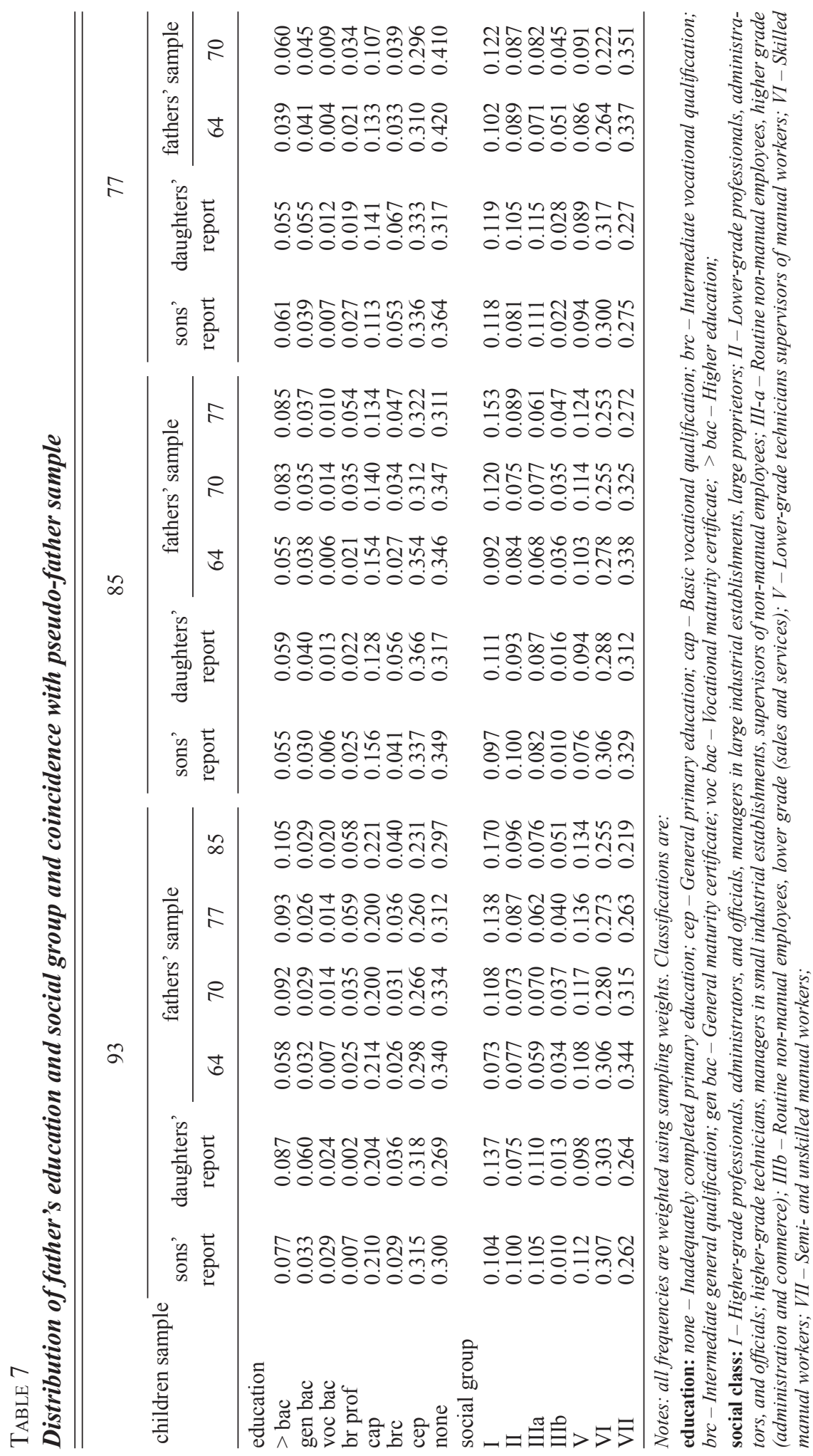


Table 8

First step estimates of father's earnings equation

\begin{tabular}{|c|c|c|c|c|c|c|c|c|c|}
\hline \multirow{3}{*}{$\begin{array}{l}\text { children sample } \\
\text { fathers sample }\end{array}$} & \multicolumn{4}{|c|}{93} & \multicolumn{3}{|c|}{85} & \multicolumn{2}{|c|}{77} \\
\hline & 64 & 70 & 77 & 85 & 64 & 70 & 77 & 64 & 70 \\
\hline & (1) & (2) & (3) & (4) & (5) & (6) & (7) & (8) & (9) \\
\hline age & $\begin{array}{r}.133 \\
(.021)\end{array}$ & $\begin{array}{r}.064 \\
(.019)\end{array}$ & $\begin{array}{r}.092 \\
(.028)\end{array}$ & $\begin{array}{r}.002 \\
(.054)\end{array}$ & $\begin{array}{r}.038 \\
(.029)\end{array}$ & $\begin{array}{r}-.0120 \\
(.028)\end{array}$ & $\begin{array}{r}-.002 \\
(.048)\end{array}$ & $\begin{array}{l}.047 \\
(.04)\end{array}$ & $\begin{array}{l}.0009 \\
(.047\end{array}$ \\
\hline age $^{2}$ & $\begin{array}{c}-.001 \\
(.0003)(\end{array}$ & $\begin{array}{l}-.0007 \\
(.0002)\end{array}$ & $\begin{array}{l}-.0009- \\
(.0003)\end{array}$ & $\begin{array}{l}-.00002 \\
(.0005)\end{array}$ & $\begin{array}{r}-.0004 \\
(.0004)\end{array}$ & $\begin{array}{l}.00009 \\
(.0003)\end{array}$ & $\begin{array}{l}-.00005 \\
(.0004)\end{array}$ & $\begin{array}{r}-.0004 \\
(.0004)\end{array}$ & $\begin{array}{l}-.00007 \\
(.0004\end{array}$ \\
\hline educ- $>$ bac & $\begin{array}{r}.390 \\
(.034)\end{array}$ & $\begin{array}{r}.409 \\
(.022)\end{array}$ & $\begin{array}{r}.471 \\
(.028)\end{array}$ & $\begin{array}{r}.318 \\
(.037)\end{array}$ & $\begin{array}{r}.529 \\
(.037)\end{array}$ & $\begin{array}{r}.456 \\
(.026)\end{array}$ & $\begin{array}{r}.601 \\
(.037)\end{array}$ & $\begin{array}{r}.491 \\
(.051)\end{array}$ & $\begin{array}{l}.544 \\
(.04\end{array}$ \\
\hline educ- bac gal & $\begin{array}{r}.281 \\
(.037)\end{array}$ & $\begin{array}{r}.360 \\
(.031)\end{array}$ & $\begin{array}{r}.327 \\
(.039)\end{array}$ & $\begin{array}{r}.173 \\
(.053)\end{array}$ & $\begin{array}{r}.319 \\
(.038)\end{array}$ & $\begin{array}{r}.393 \\
(.033)\end{array}$ & $\begin{array}{r}.376 \\
(.044)\end{array}$ & $\begin{array}{r}.348 \\
(.045)\end{array}$ & $\begin{array}{r}.386 \\
(.044\end{array}$ \\
\hline educ- bac tec & $\begin{array}{l}.265 \\
(.07)\end{array}$ & $\begin{array}{r}.341 \\
(.041)\end{array}$ & $\begin{array}{l}.331 \\
(.05)\end{array}$ & $\begin{array}{r}.217 \\
(.059)\end{array}$ & $\begin{array}{r}.426 \\
(.083)\end{array}$ & $\begin{array}{r}.302 \\
(.047)\end{array}$ & $\begin{array}{r}.330 \\
(.074)\end{array}$ & $\begin{array}{r}.437 \\
(.126)\end{array}$ & $\begin{array}{r}.235 \\
(.081\end{array}$ \\
\hline educ- br.prof & $\begin{array}{r}.24 \\
(.038)\end{array}$ & $\begin{array}{r}.234 \\
(.027)\end{array}$ & $\begin{array}{r}.318 \\
(.027)\end{array}$ & $\begin{array}{r}.226 \\
(.038)\end{array}$ & $\begin{array}{r}.32 \\
(.047)\end{array}$ & $\begin{array}{r}.233 \\
(.031)\end{array}$ & $\begin{array}{r}.312 \\
(.036)\end{array}$ & $\begin{array}{r}.438 \\
(.058)\end{array}$ & $\begin{array}{r}.171 \\
(.044\end{array}$ \\
\hline educ- cap & $\begin{array}{r}.208 \\
(.017)\end{array}$ & $\begin{array}{l}.166 \\
(.014)\end{array}$ & $\begin{array}{r}.168 \\
(.017)\end{array}$ & $\begin{array}{l}.126 \\
(.023)\end{array}$ & $\begin{array}{l}.229 \\
(.02)\end{array}$ & $\begin{array}{r}.186 \\
(.018)\end{array}$ & $\begin{array}{r}.162 \\
(.025)\end{array}$ & $\begin{array}{r}.217 \\
(.026)\end{array}$ & $\begin{array}{r}.212 \\
(.027\end{array}$ \\
\hline educ- brc & $\begin{array}{r}.235 \\
(.038)\end{array}$ & $\begin{array}{r}.209 \\
(.029)\end{array}$ & $\begin{array}{r}.223 \\
(.034)\end{array}$ & $\begin{array}{r}.154 \\
(.044)\end{array}$ & $\begin{array}{l}.269 \\
(.04)\end{array}$ & $\begin{array}{r}.229 \\
(.032)\end{array}$ & $\begin{array}{l}.289 \\
(.04)\end{array}$ & $\begin{array}{r}.267 \\
(.046)\end{array}$ & $\begin{array}{r}.278 \\
(.043\end{array}$ \\
\hline educ- cep & $\begin{array}{r}.071 \\
(.015)\end{array}$ & $\begin{array}{l}.128 \\
(.013)\end{array}$ & $\begin{array}{r}.113 \\
(.016)\end{array}$ & $\begin{array}{r}.065 \\
(.023)\end{array}$ & $\begin{array}{l}.104 \\
(.016)\end{array}$ & $\begin{array}{r}.121 \\
(.014)\end{array}$ & $\begin{array}{r}.109 \\
(.019)\end{array}$ & $\begin{array}{r}.128 \\
(.019)\end{array}$ & $\begin{array}{l}.148 \\
(.02\end{array}$ \\
\hline eg- II & $\begin{array}{r}-.35 \\
(.031)\end{array}$ & $\begin{array}{r}-.435 \\
(.023)\end{array}$ & $\begin{array}{r}-.386 \\
(.026)\end{array}$ & $\begin{array}{r}-.485 \\
(.032)\end{array}$ & $\begin{array}{r}-.382 \\
(.031)\end{array}$ & $\begin{array}{r}-.450 \\
(.026)\end{array}$ & $\begin{array}{r}-.376 \\
(.032)\end{array}$ & $\begin{array}{r}-.454 \\
(.038)\end{array}$ & $\begin{array}{r}-.461 \\
(.035\end{array}$ \\
\hline eg- IIIa & $\begin{array}{r}-.623 \\
(.035)\end{array}$ & $\begin{array}{r}-.631 \\
(.025)\end{array}$ & $\begin{array}{r}-.62 \\
(.03)\end{array}$ & $\begin{array}{r}-.718 \\
(.037)\end{array}$ & $\begin{array}{r}-.781 \\
(.036)\end{array}$ & $\begin{array}{r}-.663 \\
(.027)\end{array}$ & $\begin{array}{r}-.689 \\
(.039)\end{array}$ & $\begin{array}{r}-.940 \\
(.043)\end{array}$ & $\begin{array}{c}-.742 \\
(.037\end{array}$ \\
\hline eg- IIIb & $\begin{array}{r}-.547 \\
(.042)\end{array}$ & $\begin{array}{r}-.718 \\
(.03)\end{array}$ & $\begin{array}{c}-.718 \\
(.035)\end{array}$ & $\begin{array}{r}-.943 \\
(.043)\end{array}$ & $\begin{array}{r}-.695 \\
(.045)\end{array}$ & $\begin{array}{r}-.779 \\
(.035)\end{array}$ & $\begin{array}{r}-.801 \\
(.043)\end{array}$ & $\begin{array}{r}-.867 \\
(.05)\end{array}$ & $\begin{array}{c}-.857 \\
(.045\end{array}$ \\
\hline eg- V & $\begin{array}{r}-.305 \\
(.032)\end{array}$ & $\begin{array}{c}-.458 \\
(.022)\end{array}$ & $\begin{array}{r}-.430 \\
(.025)\end{array}$ & $\begin{array}{r}-.519 \\
(.033)\end{array}$ & $\begin{array}{r}-.402 \\
(.032)\end{array}$ & $\begin{array}{r}-.481 \\
(.025)\end{array}$ & $\begin{array}{r}-.417 \\
(.032)\end{array}$ & $\begin{array}{r}-.435 \\
(.041)\end{array}$ & $\begin{array}{c}-.499 \\
(.036\end{array}$ \\
\hline eg- VI & $\begin{array}{r}-.580 \\
(.03)\end{array}$ & $\begin{array}{c}-.758 \\
(.02)\end{array}$ & $\begin{array}{r}-.675 \\
(.024)\end{array}$ & $\begin{array}{r}-.840 \\
(.032)\end{array}$ & $\begin{array}{r}-.686 \\
(.03)\end{array}$ & $\begin{array}{r}-.787 \\
(.023)\end{array}$ & $\begin{array}{r}-.695 \\
(.031)\end{array}$ & $\begin{array}{r}-.775 \\
(.036)\end{array}$ & $\begin{array}{c}-.827 \\
(.032\end{array}$ \\
\hline eg-VII & $\begin{array}{r}-.848 \\
(.031)\end{array}$ & $\begin{array}{c}-.968 \\
(.021)\end{array}$ & $\begin{array}{r}-.823 \\
(.025)\end{array}$ & $\begin{array}{r}-.899 \\
(.034)\end{array}$ & $\begin{array}{r}-1.001 \\
(.031)\end{array}$ & $\begin{array}{r}-1.020 \\
(.023)\end{array}$ & $\begin{array}{r}-.884 \\
(.031)\end{array}$ & $\begin{array}{r}-1.100 \\
(.037)\end{array}$ & $\begin{array}{r}-1.062 \\
(.032\end{array}$ \\
\hline Const. & $\begin{array}{r}7.089 \\
(.345)\end{array}$ & $\begin{array}{r}8.897 \\
(.381)\end{array}$ & $\begin{array}{l}8.853 \\
(.644)\end{array}$ & $\begin{array}{r}11.827 \\
(1.431)\end{array}$ & $\begin{array}{r}8.896 \\
(.529)\end{array}$ & $\begin{array}{r}10.623 \\
(.648)\end{array}$ & $\begin{array}{r}11.280 \\
(1.264)\end{array}$ & $\begin{array}{r}8.681 \\
(.968)\end{array}$ & $\begin{array}{c}10.375 \\
(1.287\end{array}$ \\
\hline$\sigma$ & $\begin{array}{r}.349 \\
(.004)\end{array}$ & & & & $\begin{array}{r}.350 \\
(.005)\end{array}$ & & & $\begin{array}{r}.348 \\
(.006)\end{array}$ & \\
\hline $\begin{array}{l}\text { Obs. } \\
R^{2}\end{array}$ & 4186 & $\begin{array}{r}6488 \\
.525\end{array}$ & $\begin{array}{r}4655 \\
.489\end{array}$ & $\begin{array}{r}2672 \\
.501\end{array}$ & 3502 & $\begin{array}{r}5305 \\
.544\end{array}$ & $\begin{array}{r}3231 \\
.528\end{array}$ & 2364 & $\begin{array}{r}3543 \\
.507\end{array}$ \\
\hline
\end{tabular}

Notes: standard errors in parentheses. Columns (1), (5) and (8) are estimated using interval regression and $\sigma$ denotes estimated standard error of residuals. Regressors are: education: none (reference) - Inadequately completed primary education; cep - General primary education; cap - Basic vocational qualification; brc - Intermediate vocational qualification; brc -Intermediate general qualification; gen bac - General maturity certificate; voc bac - Vocational maturity certificate; > bac-Higher education;

social class: I (reference) - Higher-grade professionals, administrators, and officials, managers in large industrial establishments, large proprietors; II - Lower-grade professionals, administrators, and officials; higher-grade technicians, managers in small industrial establishments, supervisors of non-manual employees; IIIa - Routine non-manual employees, higher-grade (administration and commerce); IIIb - Routine non-manual employees, lower grade (sales and services); $V$-Lower-grade technicians supervisors of manual workers; VI-Skilled manual workers; VII - Semi- and unskilled manual workers; 